\title{
Meru as a Hindu Sacred Building Architecture with a High Roof and Resistant to Earthquakes in Bali, Indonesia
}

\author{
Ngakan Ketut Acwin Dwijendra \\ Faculty of Engineering, Udayana University, Bali, Indonesia
}

Received April 19, 2020; Revised June 2, 2020; Accepted June 23, 2020

Copyright $\odot 2020$ by authors, all rights reserved. Authors agree that this article remains permanently open access under the terms of the Creative Commons Attribution License 4.0 International License

\begin{abstract}
Meru has meaning as a symbol of Mount Mahameru, symbol of God and the universe that serves as a place of worship of the gods and ancestors. Meru is found in large temples in Bali, Indonesia with its trademark characteristic that the roof has a high overlapping reaching 10 meters or more with the number of roofs always odd so that Meru becomes a landmark in every temple in Bali. Meru is a very beautiful sacred building that was built based on the accuracy of proportions, the logic of construction techniques and the beauty of decoration, which holds fast to local wisdom based on Traditional Balinese Architecture. This study aims to explore the meaning and philosophy of Meru and why the construction of Meru as an earthquake resistant building. With a qualitative explorative study of primary data collection such as: surveys, observations and interviews and combined with secondary data in the form of old legacy writing, study shows that Meru not only has beauty as a sacred building but also is an earthquake-resistant building construction that has proven its reliability compared to other Hindu sacred buildings.
\end{abstract}

Keywords Meru, Hindu, Sacred Building, Architecture, High Roof, Resistant, Earthquakes

\section{Introduction}

Meru is one of the sacred buildings for Hindus in Bali, which is very regal, majestic and monumental, loaded with symbolic meaning and religious power contained therein. Meru is found in large temples in Bali with its characteristic high-overlapping roof (the roof reaches $10 \mathrm{~m}$ or more) and the number of roofs is always odd (1, 3, 5, 7, 9, 11) and only one roof overlaps 2 , so Meru became a landmark in a temple in Bali [15] [16]. Meru as a very great local work, is not only found in temples in Bali, but can also be witnessed at cremation ceremonies in Bali as corpse (sawa) containers at the Pitra Yadnya ceremony [8] [9] [18].

Meru is a very beautiful sacred building that is built based on the accuracy of proportions, the logic of construction techniques and the beauty of decoration, which holds fast to local wisdom of Balinese Traditional Architecture (Hasta Kosali Kosala, Hasta Bumi, Andha Buana Lontar, Lontar Jananthaka, etc) [23] [25] [42].

Meru construction is earthquake resistant construction that has proven its reliability compared to temple buildings or other forms. A very powerful earthquake with enormous power has ever happened in Bali (such as in Seririt District, Buleleng Regency in 1976), where many modern construction buildings have collapsed, but sacred buildings in Bali, especially Meru still stand firmly, strong, stable, and upright [19] [20] [43]. Understanding the power behind the local wisdom, this paper wants to explore the philosophy of Meru and why the construction of Meru as an earthquake resistant building.

\section{Research Method}

This research was conducted with a qualitative exploratory method by collecting data through observation, a direct survey measuring several cases of Meru objects in the biggest shrines in Bali [21] [29] [36]. Understanding of Meru is also done with secondary data, especially old writings (Lontar) and also supported by interviews with Balinese craftsmen (Undagi) who understand the concepts and philosophy and construction of Meru. From these results, the data are analyzed and expected to be able to dissect the meaning and concept of Meru and why Meru is very sturdy and resistant to earthquakes in Bali. 


\section{Results and Discussion}

\subsection{The Meaning of Meru as a Symbol of the Mountain, Worship of Gods and Ancestors}

The meaning of Meru, based on quotations listed in the lontar-ancestral heritage, as stated in the Lontar Andha Bhunana, explained that the symbolic meaning or philosophy of Meru comes from the word ' $m e$ ' means meme $=$ mother $=$ pradana tattwa, whereas ' $r u$ ' means teacher $=$ father $=$ purusa tattwa, so that the Meru has the meaning batur keletak plot (forerunner to ancestors). Meru means the symbol of andha bhuana (universe), the level of the roof is a symbol of the level of the natural layer, namely the bhuana agung (universe) and bhuana alit (human) [16] [22] [38].

Further explained that Meru has two meanings: First, Meru as a symbol or manifestation of "Mount Mahameru" and the mountain is a symbol of the universe as a stana (shrine) of the Gods, Ida Sang Hyang Widhi (God Almighty) or Papulaning Sarwa Dewata. Meru has the symbolic meaning of the mountain also described in Lontar Tantu Pagelaran, Kekawin Dharma Sunia and Usana Bali. In this case, Meru as a Pratista God is functioning as a place of worship or pelinggih of the Gods. Meru as God is found in a complex of pretenses such as: Sad Kahyangan, Kahyangan Jagat and Kahyangan Tiga Temple [1] [2] [23] (Figure 1).

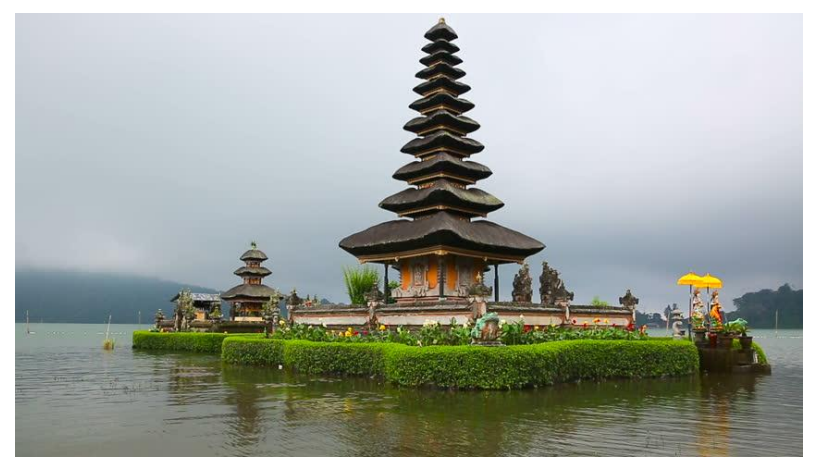

Source: https://www.shutterstock.com, 2019

Figure 1. Meru as Hindu Sacred Building

Second, Meru symbolizes "mother and father" as described in the Lontar Andha Bhuana. Mother contains the meaning of "mother earth" which is the element of tattwa pradhana and you have the meaning of "aji akasa" which is the element of purusa tattwa. The development of pradhana (woman) and purusa (man) is the great power that is the source of everything on earth. This is the basis of Meru's function as a place of worship of ancestral holy spirits in Pedarman Besakih Temple complex [15] [23]. In this case, Meru as atma pratista is functioning as a place of worship of ancestral holy spirits or as a stana (shrine) of the God of Pitara. (An ancestral spirit is said to be sacred when it has passed through the ceremonial process, which is the first cremation then followed the measuring ceremony which is the ceremony of the atman, and the last order of ceremony is the departure of the God of Pitara. After this last level ceremony Meru - Gedong Kemimitan was made [16] [24][46].

\subsection{Philosophy of Levels Contained on the Roof of Meru}

The beauty and majesty of Meru is highlighted by the beauty of its stratified roof forms called the overlapping roof, and can be distinguished into: Meru roof one, Meru roof two, Meru roof three, Meru roof five, Meru roof seven, Meru roof nine, Meru roof eleven (Figure 2).

Meru as symbolic of the universe, the level of the roof is symbolic level of the natural layer, namely bhuana agung and bhuana alit (large and small nature or macrocosm and microcosm) from the bottom up as many as eleven levels. These levels are: 1 (Sekala), 2 (Niskala), 3 (Cunya), 4 (Taya), 5 (Nirbana), 6 (Moksa), 7 (Suksmataya), 8 (Turnyanta), 9 (Ghoryanta), 10 (Acintyataya), 11 (Cayen). But there is also a Meru with a roof of 21. Meru with 21 roofs are very rare and usually this Meru can be seen in the container (bade) at the Ngaben (Pitra Yadnya Ceremony) in Bali, which has the understanding of the Dasa Dewata as the basic, then added 11 atma (soul) stairs as it goes.

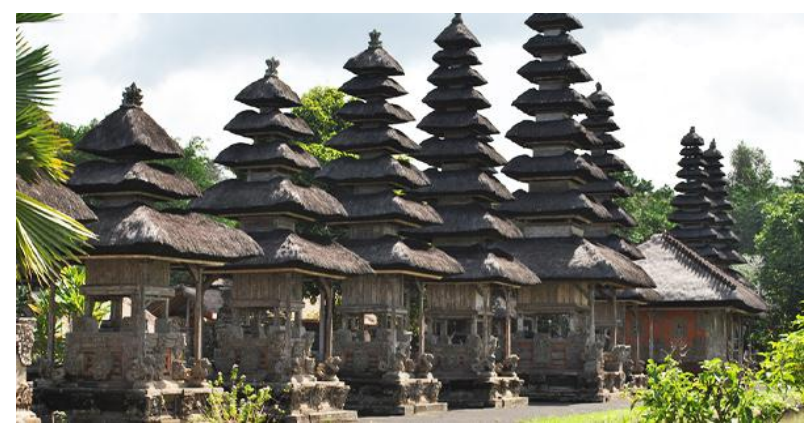

Source: https://www.shutterstock.com, 2019

Figure 2. The Beauty of Meru with a High Roof

Furthermore, the levels of the roof of the Meru are symbolic of the adoption of the dasa script (the union of the ten holy letters) as the soul (urip) of Meru or the universe [26] [23] [33]. The ten sacred letters are urip bhuana (universe soul), located in the ten corners of the universe, including the middle, the ten letters are the sacred letters of $\mathrm{Sa}$, located in the East, the God Iswara and the color is white; the sacred letters $B a$, located in the South, the God Brahma and the color red; the sacred letter $T a$, it is located in the West, its God is Mahadewa and its color is yellow; the sacred letter A, located in the north, is God Vishnu and the color is black; the sacred letter $I$, located in the middle, the God of Ciwa and the colors are mixed (five colors); the sacred letter $N a$, located in the Southeast, its God Mahesora and its color pink (dice); the sacred letter $M a$, located in the Southwest, the God Rudra and the color orange; Si holy letters, located in the Northwest, God Sangkara and green color; $\mathrm{Wa}$ sacred letters, it is located in 
the Northeast, Sambu's Dew and the color is blue and the last is the Sacred $\mathrm{Ya}$. The ten letters singularity becomes a symbol of the sacred scriptures for Hindus, namely Omkara (the holy letter Sanghyang Widi Wasa, God Almighty).

Table 1. Number of Meru Roofs, Sacred Letters and Symbols

\begin{tabular}{|c|c|c|}
\hline $\begin{array}{l}\text { Number of } \\
\text { Rooftops }\end{array}$ & Sacred Letters & God Symbol \\
\hline 11 & $\begin{array}{c}\mathrm{Sa}, \mathrm{Ba}, \mathrm{Ta}, \mathrm{A}, \mathrm{I}, \mathrm{Na}, \mathrm{Ma}, \mathrm{Si}, \mathrm{Wa}, \\
\text { Ya }+ \text { Omkara }\end{array}$ & $\begin{array}{l}\text { Eka Dasa } \\
\text { Dewata. }\end{array}$ \\
\hline 9 & $\begin{array}{c}S a, B a, T a, A, N a, M a, S i \\
W a+\text { Omkara }\end{array}$ & Nawa Sanga. \\
\hline 7 & Sa, Ba, Ta, A+I, Omkara, Ya & $\begin{array}{c}\text { Sapta } \\
\text { Dewata/Rsi }\end{array}$ \\
\hline 5 & $S a, B a, T a, A+$ Omkara & Panca Dewata. \\
\hline 3 & I, Omkara, Ya & Tri Purusa \\
\hline 2 & $I, Y a$ & $\begin{array}{c}\text { Purusa } \\
\text { Pradhana. }\end{array}$ \\
\hline 1 & OM/Omkara & God Almighty \\
\hline
\end{tabular}

Source: Author Analysis, 2017

The number of Meru roofs and sacred letters (as seen at Table 1) can be described as follows:

1. Meru roofed eleven (11) is a symbol of eleven holy letters, namely ten sacred letters ( $\mathrm{Sa}, \mathrm{Ba}, \mathrm{Ta}, \mathrm{A}, \mathrm{I}, \mathrm{Na}$, $\mathrm{Ma}, \mathrm{Si}, \mathrm{Wa}, \mathrm{Ya}$ ) plus Omkara sacred letters as a symbol of Eka Dasa Dewata.

2. A nine (9) roof is an 8 letter symbol in all directions ( $\mathrm{Sa}, \mathrm{Ba}, \mathrm{Ta}, \mathrm{A}, \mathrm{Na}, \mathrm{Ma}, \mathrm{Si}, \mathrm{Wa}$ ) plus one Omkara letter in the middle, 9 letters are symbols of the Gods Nawa Sanga.

3. A seven (7) roof is a 4-letter symbol throughout East, South, West and North ( $S a, B a, T a, A)$ plus three letters in the middle (I, Omkara, Ya). These seven letters symbolize the Sapta Dewata/Rsi.

4. Five (5) roofs are symbolic of the five letters namely East, South, West, North $(S a, B a, T a, A)$ plus one Omkara letter in the middle, these five letters symbolize the Panca Dewata.

5. Three (3) roofs are symbolic of the three letters in the middle (I, Omkara, Ya) as a symbol of Tri Purusa, namely Parama Shiva, Sada Shiva and Shiva.
6. The two-story roof (2) is symbolic of the two letters in the middle $(I, Y a)$ that are the symbol of Purusa and Pradhana.

7. One roof (1) is symbolic of the unification of the ten sacred letters, namely 'Om' or omkara as a symbol of the One God (Sanghyang Widi Wasa or God Almighty).

\subsection{Layout and Form of Meru Based on Hasta Kosala Kosali's Rule}

Meru in layout is in a place of worship on the main yard (jeroan) of a temple [12] [17] [33]. In terms of orientation, Meru generally faces west as the main place of worship lined on the east side from north to south (kaja-kelod) with padma, gedong and other sacred worship buildings so that the direction of worship faces east toward the sunrise. But in some temples in Bali related to the special natural and philosophical conditions of the temple, there are meru facing south (kelod) such as Kehen Temple, Bangli and facing northeast (kaja kangin) like Uluwatu Temple, Badung so that the direction of worship faces towards north (Kehen Temple) and Kelod Kauh/Southwest (Uluwatu Temple).

In terms of form, Meru like other sacred buildings are distinguished from the head (roof), body (worship room or place to put pratima) and feet (bebaturan) or known as the Tri Angga Concept [16] [23]. Although Meru can be divided into three parts, namely the legs, body parts and roof section, the proportions and settlement are very different both in the settlement of the proportions of the body, visible body (worship space), completion of the overlapping roof and the use of ornaments and materials also vary accordingly with the condition of each region in Bali (desa, kala, patra) based on observations on Meru in the Besakih Temple, Batur Temple, Taman Ayun Temple, Kehen Temple, Lake Beratan Temple, etc. Whereas in terms of dimensions, the Meru floor plan is rectangular in shape with a base size varies, $5 \mathrm{~m} \times 5 \mathrm{~m}, 3 \mathrm{~m} \times 3 \mathrm{~m}$, up to 7 $\mathrm{m} \times 7 \mathrm{~m}$ and its height varies to reach $10 \mathrm{~m}$ even more depending on the number of overlapping roofs (Figure 3 ). 

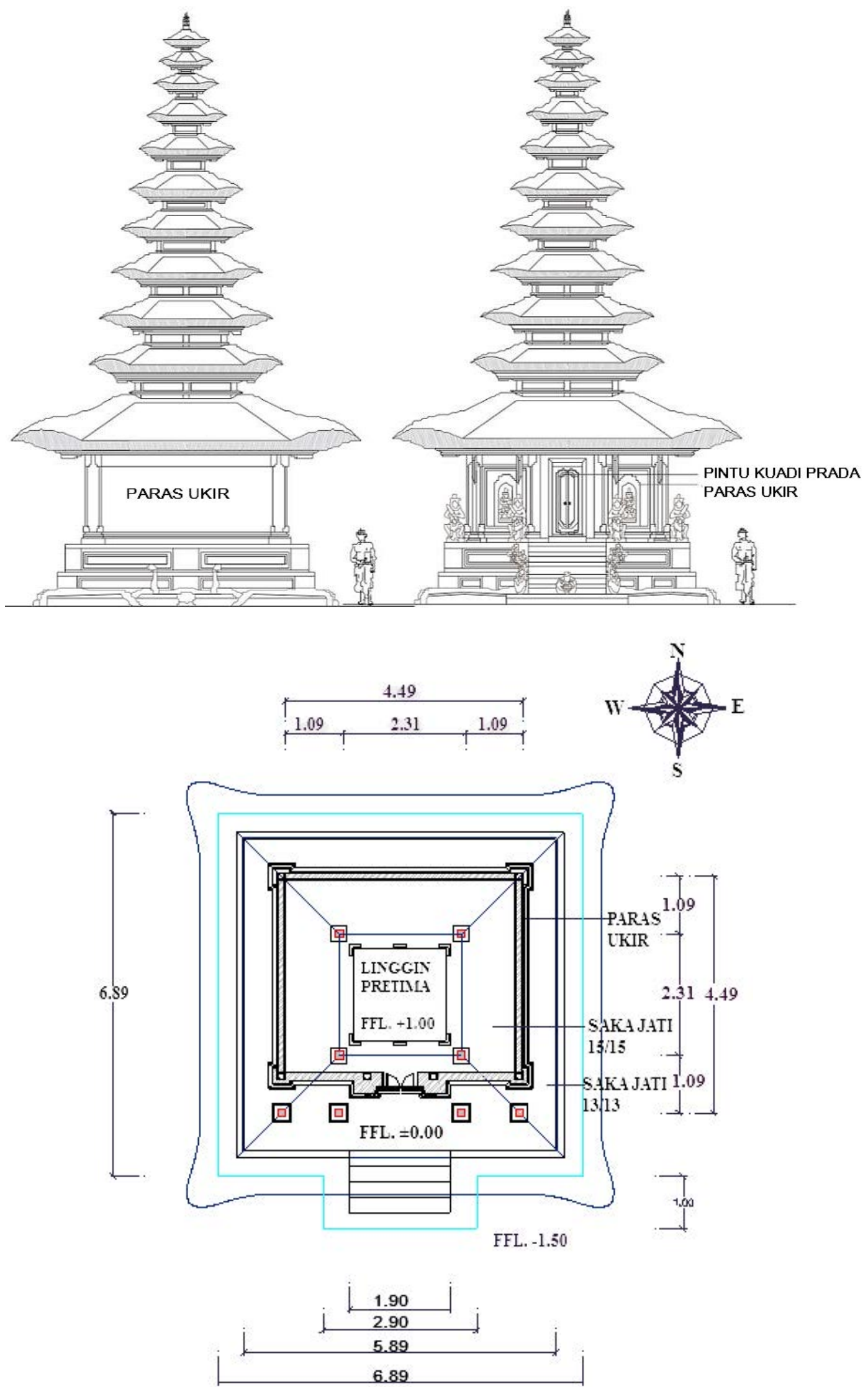

Source: Author, 2017

Figure 3. Layout and Elevation of Meru Sacred Building 
On the part of the body that is the place of worship, covered by using wood or a pair of bricks, river stones, sandstone (according to site conditions) and in it there is a pepaga (altar) or bale-bale that serves as a place to put pratima in the form of phallus, statues of gods and goddesses as a symbol of the manifestation of the power of Hyang Widi Wasa (God Almighty), and offerings at the time of the ceremony and are equipped with an entrance for humans to pray in the room/body of Meru [37] [41] [44]. The character in this worship room has a high verticalism, so as if we are pulled up, this is caused by the influence of the shape of the space inside it continuously from the bottom up, so that there is an upward air pull which blows through the gaps between the overlaps Meru roof.

In terms of the shape of the body (feet), Meru is distinguished from Meru with bebaturan tall and short shapes. In terms of mass stability, the form of Meru with a short shelf will be more stable than a tall shelf. This stability is closely related to the center of mass of the building. Generally, Meru with a short shelf is often found in temples in the mountains, besides being more stable also because the ornament or ornamental decoration on the legs (bebaturan) will be less or more economical. But in general, the shape and dimensions of Meru are based on the rules of Hasta Kosala Kosali (Balinese Traditional Architecture Script) so as to produce harmony between the accuracy of proportions, strength of construction and beauty of decoration [10][23][47][48].

\subsection{Meru's Ornaments Symbolize the Harmony of Man and Nature}

The ornaments on Meru are almost similar to other sacred temples which are laden with ornaments in the form of kekarangan (fauna ornaments) and pepatraan (flora ornaments) which show the harmony of humans with nature, symbolizing flora and fauna. Ornaments on the tip of the Meru peak roof are classified into the head, we generally find ornaments called murdhas such as the Murdha Bantala at Meru in Besakih Temple, which at the same time function as the top of the roof cover, while around the roof there are ornaments on the listplank called ring-ring with variations in the form of carvings in the form of papapatraan like patra sae.

Ornaments of the body parts of Meru, especially at the top of the gedong door, usually have coral ornaments. The doors usually use carved motifs patra olanda. Furthermore, on sendi (joints) or tatakan saka (column) using a lion statue like the one in Meru of Besakih Temple, there are also those who wear ordinary joints like those in Meru in Batur Temple.

Ornaments is found in the legs (bebaturan) in the form of pepalihan, karang asti/Karang Gajah in each corner, karang tapel in the middle on all four sides at the most basic on the edge of the rain. Then at the top there are karang goak in all four corners and karang bunga and simbar gantung in the middle. Ornaments in the form of statues of Naga (dragon) and Bedawang Nala (turtles) can usually be seen at the base of the feet and stairs of Meru, where the dragon and turtle as a symbol of prosperity is also equipped with other statues in accordance with the conditions of each temple such as: statue gods, human statues and others.

\subsection{The Use of Materials in Meru Refers to Local Materials}

The material for the head that is the roof cover is generally adapted to the natural condition of the location of the sacred building such as, in the northern Bangli regency the roof cover consists of bamboo shingles, the roof covering in Sebatu-Gianyar Village is derived from enau wood (bon jaka) and in Taro Village the roof cover consists of palm fibers, and in some villages it is easy to get the reeds using the dried alang-alang leaves. However, in some regions or villages there are written provisions for the roof covering of sacred buildings such as Meru required to use a palm roof, philosophically it is believed that the palm fiber has magical religious powers, and the strength of the palm fiber material has very strong durability compared to traditional roof coverings the other.

Parts of the body such as material in saka (column), horizontal beam (lambang, sunduk, sineb), titi mamah (pedestal beam) and canggahwang (supporting beam) use wood as the main material. Whereas for gedong (pratima storage area), some places use wood materials such as in Batur Temple and some temples use solid stone or brick material such as in Besakih Temple and Jati Temple [13] [14] [23].

Meru buildings include or are classified as parhyangan buildings, so the types of wood used should come from the sandalwood kingdom with classifications such as: Prabu (sandalwood), Patih (menengen wood,) Arya (cempaka wood), Demung (majegau wood) and Tumenggung (suren wood). Then the quality of the wood that is used both strength and durability must also be of high quality considering that there are lots of overlapping meru. It will be very difficult to carry out repairs if damage occurs [7] [5] [6] [11].

In its processing basically the above material is also considered as a living organ so that its location should not be reversed at the base and its designation, for example sandalwood as a prabu (king) class is generally used for disasters (peak construction roofs). Besides the requirements mentioned above, other important matters relating to wood material that must be considered are at the time of logging, namely the procedure for felling timber in its felling (northeast/main, north and east/middle and southeast, south, west, southwest, northwest/nista) and checking the quality of wood that is classified as defective according to traditional Balinese rules such as: wood that grows on shrines plots and graves; wood that grows on 
stems that have been cut down; wood growing on the border of the yard, on the edge of a cliff, alongside a river; old wood drifted away; burnt wood/lightning; felled wood crosses a river or road; the felled timber fell on the base; and wood that collapses or is blown by the wind against other trees or collapses against a wall [3] [4] [15] [23].

At the foot or bebaturan use stone padas, river stones, sea rocks, hill rocks, bricks such as in Batur Temple and Taman Ayun Temple, and there are also temples that use Karangasem tabas stone. But in general the stone material used is adapted to local conditions.

\subsection{How do Meru's Structure and Construction Make It Resistant to Earthquakes?}

Meru is a parahyangan building where the shape of the building uses the form of overlapping roofs. The structure of the building uses a very efficient frame structure system to withstand the load in the presence of a pole (saka) as a distributor of vertical loads and sineb-lambang beams, diagonal beams as a pedestal pole (titimamah) as a horizontal load divider (Figure 4).
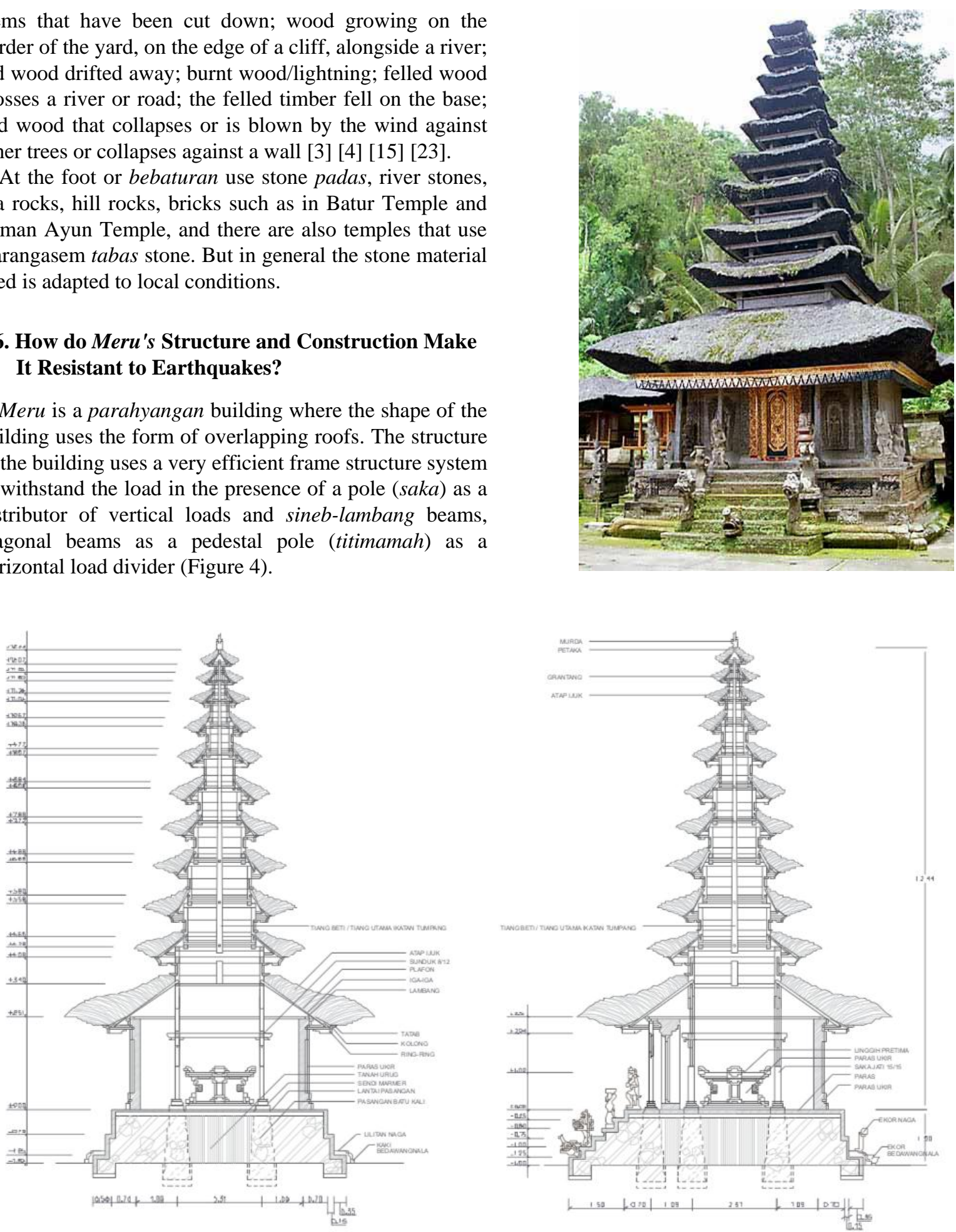

Source: Author, 2017.

Figure 4. Structure and Construction of Meru which is Holy and Earthquake Resistant 
On the roof, the construction consists of ribs (usuk) with dimensions and installation distance that is able to withstand the weight of the roof made of palm fiber. Then the existence of petaka (ridge beams) as a binder of ribs (usuk) on the top of the roof overlap which has a very large role in holding the load so that the dimensions of the disaster are generally made with large enough dimensions [15] [31] [32].

Overlapping construction is placed on the titimamah (pedestal beam) which is the pedestal of the overlapping mast load channel which decreases upward at each overlap. The corners of the pyramid roof with the pyramid form are stuck. The roof body on it stands on the roof of the roof below, the pillar rests on the beam. The roof at the top has one peak with a bond in the form of petaka (ridge beams) that is closed murdha as the top of the roof covering.

Considering that titmamah (pedestal beam) has a very important role as a distributor of loads on it, the placement must be exactly in line with sukat (traditional Balinese dimension) and the planned meru roof overlap, so that even if the overlap is a little the proportion will still give the impression of mounting. In some areas in Bali, meru roof overlaps, especially those with high lifts, in addition to titimamah bonds, some also use beti poles, one main room in the middle of the trunk as a whole roof overlap to overcome large wind loads that will endanger the construction whole [15] [23] 27][51][56].

After that, the load will be channeled to the beam of sineb and lambang as a horizontal load channel, which then the load is channeled to the pole (saka) made with dimensions according to the rules from top to bottom considering saka as a large vertical channel distributor. In traditional Balinese rules (Hasta Kosala Kosali), the cross section of the pole (saka) is of amusti size, along the grip and the base line to the tip of the finger $\pm 15 \mathrm{~cm}$ [15] [23][52]. Then the measurements of the distance of the pile to the pile and the height of the pile at each overlap level and other parts are determined from the multiple of the rai or cross section of the amusti pile at the very bottom. Overlapping levels above the proportion also decreases to the top. Each measure of the multiples of the cross-section of the pillars, called rai, is given an excess called pengurip (soul) from the parts of the fingers [23] [34][49][50].

Meru construction with bonding holes reinforced with pegs or wedges without nails. Roof construction with clasps and ties. The bottom frame is a series of four corner pillars and reinforcement, stiffener and complement constructions. For large Meru, in addition to the angle pole, there is also a side pole. The row poles are another supporting edge of the roof below.

Part of the gedong is as a place of worship and place of pratima, formed by four corner pillars arranged by sunduk-lait below and lambang sineb beam above. The board walls are on the back and right and left sides, while the front is the entrance to the gedong with traditional Balinese form and construction. But in some areas, worship spaces are formed by masonry or brick walls. The shape of the sunduk and lait is usually done in an attractive manner so that it has aesthetic value in the building. Likewise, between the sineb-lambang beam and the pole (saka) connected by supporting beams called canggahwang (supporting beam) so that it adds strength in bearing the burden and has beauty. As for sub-structures, meru's foundation uses local foundations at the point of placement of the pillar (saka) and a continuous foundation around the boundaries of the rocks which are attached to the rocks and kekarangan (fauna ornaments) [35] [40].

All elements of the structure are made with dimensions that are in accordance with the procedures or rules of Hasta Kosala-Kosali (Balinese Tradisional Architecture Script) and good quality materials so that their construction is able to withstand the burden of both wind, earthquake, thermic, and other loads very effective, sturdy, strong and stable [15] [23] [45][51]. Besides that, the completion of some parts of structural elements have very beautiful shapes so that the elements are not only sturdy and stable to withstand the load but also have a very high aesthetic value [28] [30] [39][52][53][54].

\section{Conclusions}

Based on the description above that Meru has a meaning as a symbol of Mount Mahameru, a symbol of God Almighty and Mother-Father functions as a place of worship of the Gods and ancestral holy spirits. All structural elements in Meru are made with dimensions that are in accordance with the procedures or rules of traditional Balinese architecture (Hasta Kosala Kosali) and with good quality materials so that the construction of the Meru is able to withstand wind, earthquake, thermic, and other loads. The completion of some structural and construction elements has a very beautiful shape so that the elements are not only sturdy and stable to withstand the load but also have a very high aesthetic value. So that the structure and construction of Meru is a building with sacred meaning and symbolic and structurally construction as an earthquake resistant building that has proven its reliability compared to other sacred buildings.

\section{REFERENCES}

[1] I. M. Adhika, N. K. A. Dwijendra. Selfie Photos Area and Its Implication to Water Availability and Social Culture in Wanagiri Village, Bali Indonesia, International Journal of Psychosocial Rehabilitation, Vol. 24, No. 4, 2020, DOI: 10.37200/IJPR/V24I4/PR201652.

[2] I. W. Ardika, I. G. Parimartha, A.A. B. Wirawan. Sejarah Bali dari Prasejarah Hingga Modern, Udayana University Press, Denpasar Indonesia, 2015. 
[3] I. G. A. Wesnawa, Implementation of Tri Hita Karana Concept in Rural Settlement Environment (Case of Badung Regency of Bali Province), Journal of Sustainable Lands, Vol. 10 No. August 2, 2010: 295-301, 2010.

[4] Bakhtiar, et al, Type of Theory on Archipelago Architecture by Josef Prijotomo, Journal of NALARs, ISSN 1858 1137, Vol. 11 No. August 2, 2014: 32-47, 2014.

[5] C. Barker, Cultural Studies Teori dan Praktik, PT. Bentang Pusaka, Yogyakarta Indonesia, 2005.

[6] C. Barker, Kamus Kajian Budaya, PT. Kanisius Yogyakarta Indonesia, 2014.

[7] G. Broadbent, Design in Architecture, John Wiley and Sons, London, 1973.

[8] E. Budiharjo, Architecture Conservation in Bali. Gajah Mada Univerity Press, Yogyakarta Indoneseia, 1996.

[9] M. Covarrubias, Island of Bali, Oxford University Press, Kuala Lumpur, 1974.

[10] M. Danesi, Pesan, Tanda, dan Makna, Jalasutra, Yogyakarta Indonesia, 2011

[11] N. L. P. D. Dharmayanty, S. A. Paturusi, N. K. A. Dwijendra, N. K. A. Dewi, Development and Behaviour Response of the Balinese Inhabitting in Denpasar City and Badung Regency, Bali-Indonesia. Journal of Social and Political Sciences, Vol.2, No.2, 455-467, 2019.

[12] N. K. A. Dwijendra, Perumahan dan Permukiman Tradisional Bali. Permukiman "Natah", 01(01), 8-24, 2003.

[13] N. K. A. Dwijendra, Affordable Housing Provision Projects in Bali, Indonesia: Improving Quality and Cultural Acceptability. (Doctoral), Curtin University. Retrieved from http://hdl.handle.net/20.500.11937/2042, 2014.

[14] N. K. A. Dwijendra, Bali Traditional Housing and Settlements. Journal of Settlement Natah, Vol. 1 No. February 1, 2003: 8-24, 2003.

[15] N. K. A. Dwijendra, Arsitektur Bangunan Suci, Berdasarkan Asta Kosala Kosali, Udayana University Press, Denpasar Indonesia, 2008.

[16] N. K. A. Dwijendra, Arsitektur Rumah Tradisional Bali, Berdasarkan Asta Kosala Kosali, Udayana University Press, Denpasar Indonesia, 2008.

[17] N. K. A. Dwijendra, Arsitektur Kebudayaan Bali Kuno, Udayana University Press, Denpasar Indonesia, 2009.

[18] N. K. A. Dwijendra, Arsitektur Tradisional Bali di Ranah Publik, Udayana University Press, Denpasar Indonesia, 2010.

[19] N. K. A. Dwijendra, 'Transformation of Traditional Housing in Bungaya Village, Karangasem Bali, Indonesia', International Journal of Current Advanced Research, 08(01), pp. 16793-16798. DOI: http://dx.doi.org/10.24327 /ijcar.2019.16798.3118, 2019.

[20] N. K. A. Dwijendra, Morphology of House Pattern in Tenganan Dauh Tukad Village, Karangasem Bali, Indonesia. Journal of Social and Political Sciences, Vol.2, No.1, 173-181, 2019.

[21] N. K. A. Dwijendra, Identity Struggle Perspective in
Car-Shaped Shrine in Paluang Temple, Nusa Penida Bali, Indonesia, International Journal of Psychosocial Rehabilitation, Vol. 24, No. 4, DOI: 10.37200/IJPR/V24I4/PR201653, 2020.

[22] N. K. A. Dwijendra, N. P. Sueca, The Determinant Factor of Home Transformation in Bali, Indonesia, The Journal of Social Sciences Research, Vol. 5, No. 12, pp 1855-1860, 2019.

[23] I. N. Gelebet, Traditional Balinese Architecture, Ministry of Education and Culture Project Inventory and Documentation of Regional Culture, Denpasar Indonesia, 1986.

[24] I. W. Geriya, 'The concept and strategy of revitalizing local wisdom in the environment of Bali', in AAGR Dalem, IW Wardi, IW Suarna \& IWS Adnyana (eds), Local wisdom in environmental management, Udayana University Publishers, Denpasar, pp. 52-60, 2007.

[25] Goris, R. (1948). Sejarah Bali Kuno (Singaraja: tanpa penerbit, Oktober-November 1948), p.16, 1948.

[26] Hooykaas, C. (1980). Drawings Of Balinese Sorcery. Institute Of Religious Iconography State University Groningen. Leiden EJ Brill: Tuta Sb Aegide Pallas. EJB, 1980.

[27] H. Kagami, Balinese traditional architecture in process, the Little World Museum of Man, Inuyama Japan, 1988.

[28] R. Krier, Architectural Composition. Translation Edition. Erland Indonesia, Jakarta Indonesia, 2001.

[29] Lubis, Akhyar Yusuf. (2014). Teori dan Metodologi Ilmu Pengetahuan Sosial Budaya Kontemporer. Jakarta: Rajawali Pers, 2014.

[30] C. B. McCullagh, The Logic of History: Putting Postmodernismin Perspective. Routledge, London, 2004.

[31] N. M. A. Wiryasa, N. K. A. Dwijendra, Institutional Structure Models in Implementation of Spatial Planning. Journal of Sustainable Development; Vol. 10, No. 4; 2017 ISSN 1913-9063 E-ISSN 1913-9071. Published by Canadian Center of Science and Education, 2017.

[32] N. M. E. Nutrisia Dewi, N. K. A. Dwijendra, 'Transformation of Bale Daja Architecture in Housing of Sading Village, Badung, Bali, Indonesia', International Journal of Current Advanced Research, 07(6), pp. 13221-13225. DOI: http://dx.doi.org/10.24327/ijcar.2018.13225.2347, 2018.

[33] H. S. Nordholt, Bali: colonial conceptions and political change 1700-1940 from shifting hierarchies to 'fixed' order, Rotterdam: Erasmus, 1986.

[34] N. P. S. Nurjani, N. K. A. Dwijendra, How Traditional Balinese Houses Can Adjust and Cater for International Tourist in the Canggu Area, Bali Indonesia? In: International Journal of Psychosocial Rehabilitation, Vol. 24, No. 03, DOI: 10.37200/IJPR/V24I3/PR201901, 2020.

[35] N. P. S. Nurjani, S. A. Paturusi, N. K. A. Dwijendra, and Putra, I. D. G. A. Diasana, Morphology of Backpacker Dormitory Inside Traditional Balinese House, Canggu Village, Bali, Indonesia. In: Journal of Social and Political 
Sciences, Vol.2, No.3, 514-521, 2019.

[36] M. Q. Patton, Qualitative Evaluation Method. Sage Publications, London, 1980.

[37] M. Picard, Bali: cultural tourism and touristic culture, Archipelago Press, Singapore, 1996.

[38] W. J. S. Poerwadarminta, Kamus Besar Bahasa Indonesia. Balai Pustaka, Jakarta Indonesia, 1989.

[39] H. M. Proshansky, et al. 'Place identity: physical world socialization of the self', Journal of Environmental Psychology, vol. 3, pp. 57-83, 1983.

[40] [40] [40] I. W. Runa, "Sejarah Arsitektur Tradisional Bali”, Pustaka Arsitektur, Bali Indonesia, 2008.

[41] E. Shils, 'Tradition', Comparative Studies in Society and History, vol. 13, no. 2, Special Issue on Tradition and Modernity, pp. 122-159, 1971.

[42] J. L. Swellengrebel, Introduction, in JL Swellengrebel (ed), Bali: studies in life, thought, and ritual, Foris Publication Holland, Nethelands, pp. 1-76, 1984.

[43] R.E. Wood, 'Tourism, culture and the sociology of development', in K Hitchcook \& Parnwell (eds), Tourism in South-East Asia, Routledge, London, pp. 48-70, 1993.

[44] M. V. Yogantari, N. K. A. Dwijendra, Visual Exploration Using Acrylic Paint on Used Fashion Items for Sustainable Use. In: International Journal of Psychosocial Rehabilitation, Vol. 24, No. 03, DOI: 10.37200/IJPR/V24I3/PR201902, 2020.

[45] Ngakan Ketut Acwin Dwijendra. (2020). From Tradition to Modernization in Morphological Process of Indigenous Settlement Patterns in Bali, Indonesia. International Journal of Advanced Science and Technology, 29(8s), 172 - 184. Retrieved

fromhttp://sersc.org/journals/index.php/IJAST/article/view /1043.

[46] Ni Luh Putu Dessy Dharmayanty, Syamsul Alam Paturusi, Ngakan Ketut Acwin Dwijendra, Ni Ketut Agusinta Dewi, The Meaning of Vertical Housing for Balinese People, the Debate between Cultural Demands and the Need for Urban Housing in Bali, Indonesia. In: International Journal of Psychosocial Rehabilitation, Vol. 24, No. 7, DOI: 10.37200/IJPR/V24I3/PR201902, 2020.

[47] Ngakan Ketut Acwin Dwijendra, I Made Adhika, I Dewa Gede Agung Diasana Putra I Gusti Putu Bagus Sastrawan Mananda, Ida Bagus Putu Adnyana. (2020). Design Model Innovations for Tourism Villages In Bangli, Bali Indonesia: Debate Between Environmental And Cultural Protection Versus Community Economic Development. International Journal of Advanced Science and Technology, 29(7), 1428 - 1443. Retrieved from

http://sersc.org/journals/index.php/IJAST/article/view/155 56.

[48] Agus Kurniawan, Putu Rumawan Salain, Ngakan Ketut
Acwin Dwijendra, and I Gusti Ngurah Anom Rajendra. (2020). Revealing the Meaning Behind Mandala of Agung Karangasem Palace, Bali Indonesia: Investigating Through Semiotics For Preservation Of Historic Value. International Journal of Advanced Science and Technology, 29(7), 1417 1427. Retrieved fromhttp://sersc.org/journals/index.php/IJ AST/article/view/15555.

[49] Ngakan Ketut Acwin Dwijendra. I Putu Gede Suyoga (2020). Analyze of Symbolic Violence Practices in Balinese Vernacular Architecture, Bali Indonesia. International Journal of Innovation, Creativity and Change, Vol. 11, Issue 14, 2020.

[50] Ida Bagus Idedhyana, Ngakan Putu Sueca, Ngakan Ketut Acwin Dwijendra and Ida Bagus Wirawibawa, (2020). Architecture of Padmasana Tiga in Besakih Temple, Bali Indonesia: Interpreted from the Concept of Shiva Siddhanta. International Journal of Advanced Science and Technology, Vol. 11, Issue 14, 2020.

[51] N. K. A. Dwijendra, Laila Refiana Said, Totok Hendarto, Samuel PD Anantadjaya (2020). The green supply chain management practices effect in the context of Indonesian community empowerment and poverty reduction. Journal of Talent Development and Excellence (TDE), Vol. 12 No. 4s (2020).

[52] Frysa Wiriantari, Syamsul Alam Paturusi, Ngakan Ketut Acwin Dwijendra and I Dewa Gede Agung Diasana Putra (2020). The Value of Catuspatha as a Public Space for the Balinese Community in the Klungkung City, Bali Indonesia: The Struggle for Activities between Politics, Economics and Socio-Culture. International Journal of Advanced Science and Technology, Vol. 11, Issue 14, 2020.

[53] N. K. A. Dwijendra. (2020). Expanding Oil \& Gas Sector of Indonesia through Better Marketing Performance: Analyzing the Role of Online Engagement, Interactivity and Brand Attachment. International Journal of Innovation, Creativity and Change, Vol. 11, Issue 14, 2020.

[54] N. K. A. Dwijendra. (2020). Innovative Work Behaviors in Pharmacies of Indonesia: Role of Employee Voice, Generational Diversity Management and Employee Engagement. Systematic Reviews in Pharmacy, Vol 11, Issue 5, May 2020.

[55] I Made Agus Mahendra, Syamsul Alam Paturusi, Ngakan Ketut Acwin Dwijendra and I Dewa Gede Agung Diasana Putra (2020). The Meaning of Local Culture Elements and Urban Elements as Forming the Identity of the Klungkung Urban Area, Bali, Indonesia. International Journal of Advanced Science and Technology, Vol. 12, Issue 12, 2020.

[56] Ngakan Ketut Acwin Dwijendra, I Dewa Gede Agung Diasana Putra (2020). Collaboration and Acculturation to Manage and Create Architectural Design of Giri Natha Temple, Timor Leste: The Architectural Harmony between Bali and Timor Leste. Journal of Talent Development and Excellence (TDE), Vol. 12 No. 3s (2020) Page No: 32523267. Retrieved from http://iratde.com/index.php/jtde/artic le/view/1352.. 